\title{
Gall traits and galling insect survival in a multi-enemy context
}

\author{
Uiara Costa Rezende ${ }^{1}$, João Custódio Fernandes Cardoso $^{1}$, P. Hanson ${ }^{2} \&$ D. C. Oliveira ${ }^{1 *}$
}

1. Laboratório de Anatomia, Desenvolvimento Vegetal e Interações, Programa de Pós-Graduação em Ecologia e Conservação de Recursos Naturais, Universidade Federal de Uberlândia (UFU) Campus Umuarama, Rua Ceará s/n, Uberlândia, Brasil; uiara.ucr@gmail.com, jcfclg@gmail.com (*Correspondencia).

2. Escuela de Biología, Universidad de Costa Rica, Ciudad Universitaria Rodrigo Facio, San Pedro, San José, Costa Rica; phanson91@gmail.com

\section{Received 08-VII-2020. Corrected 02-XII-2020. Accepted 08-XII-2020.}

\begin{abstract}
Introduction: The enemy hypothesis postulates that gall traits protect galling insects against natural enemies. Galls show a huge range of sizes, colors and ornaments, which vary even intraspecifically. However, galling insects are targets of various organisms that attack them directly or indirectly. In this context, to consider only one gall trait to investigate gall structure acting against only one guild of enemies can conceal an understanding of the community-level interactions. Objective: Herein, we take these ideas into consideration to investigate the conspicuous galls induced by Palaeomystella oligophaga Becker and Adamski 2008 (Lepidoptera) on Macairea radula (Bonpl.) (Melastomataceae) as a model system. We characterize this system through categorization of the different enemy guilds present in the community. We identified them to the lowest taxonomic level possible and determined the kind of interaction responsible for galling insects' deaths. Considering the enemy hypothesis and the selection of secondary characteristics, we also aimed to determine which of the multiple gall traits influence the survival success of galling insects in a multi-enemy context. Methods: We inspected galls and characterized the enemy guilds affecting the galling insect and the mortality rates produced by each one of them. Next, we tested whether the distinct gall traits measured (parenchyma thickness, color, projections) promote galling insect survival with respect to each enemy. Results: The mortality induced by indirect enemies (organisms that interact with gall tissues and can interact secondarily with galling insect) was $47.3 \%$, being higher than that caused by parasitoids and predators (31.5\%). Despite the gall's structural complexity, live galling insects showed the smallest occurrence (21.2\%). Parenchyma thickness was negatively related to Calliephialtes parasitoids, Gelechiidae cecidophages and predation signals. Conclusions: We demonstrated that the attacks to gall tissues by the cecidophages represented the highest threat to P. oligophaga survival, being higher than the mortality caused by direct enemies. That is, the gall traits were not as efficient as supposed to protect the galling insect from the attack of natural enemies. Nevertheless, we also demonstrated that parenchyma thickness can be negatively related to some organisms, especially direct enemies. Other traits hypothesized as defensive (e.g. projections, coloration) may simply play no role.
\end{abstract}

Key words: gall morphology; indirect interactions; multitrophic; tritrophic; cecidophages; anthocyanin.

Costa Rezende, U., Fernandes Cardoso, J.C., Hanson, P., \& Oliveira, D.C. (2021). Gall traits and galling insect survival in a multi-enemy context. Revista de Biología Tropical, 69(1), 291-301. DOI 10.15517/rbt.v69i1.42826

Some insects have adapted to control and redirect the growth, differentiation and physiology of host plant organs to their own advantage and form galls (Mani, 1964; Price, Fernandes, \& Waring, 1987; Stone \& Schönrogge, 2003;
Oliveira et al., 2016). This kind of interaction may be considered the most complex plantinsect association, with the galling organism acting as a sophisticated herbivore (Shorthouse, Wool, \& Raman, 2005). Several hypotheses 
have been raised to explain the pervasive adaptive radiation of galls (Price et al., 1987). One of these proposes that the galling habit might evolve as an adaptation related to desiccation pressure on insect larvae, since the mechanical structure can provide an ideal microclimatic habitat (Danks, 2002; Lill, Marquis, Cuddington, Byers, \& Wilson, 2007). Another hypothesis suggests that the gall formation may be related to the absence of foraging behavior, once within the gall, the galling insect can obtain nutrients directly from the specialized tissue, the nutritive one (Mani, 1984; Shorthouse, 1986; Bronner, 1992; Rezende, Cardoso, Kuster, Gonçalves, \& Oliveira 2019). Finally, the enemy hypothesis states that the plant host tissues surrounding the galling insect protect it against attack by natural enemies (Price \& Pschorn-Walcher, 1988). In addition to that, the selective pressure imposed by natural enemies have been discussed as a main driver to explain the morphological diversity of galls (Stone \& Schönrogge, 2003; Bailey et al., 2009).

Considering the several traits suggested as defenses for galling insects, conspicuous gall coloration seems to be the most intriguing (Inbar et al., 2010a, Inbar et al., 2010b; White, 2010; Lev-Yadun, 2016). Among the many ideas proposed for gall color (Bomfim et al., 2019), the aposematic hypothesis raised by Inbar et al. (2010a), that galls with conspicuous colors (as red color) may be aposematic and protected the galling insect by the presence of chemical compounds - deserves special attention and should be tested for validation. The formation of trichomes and projections is considered as a plant defense against herbivores (Yamazaki \& Lev-Yadun, 2015; Alahakoon et al., 2016; López-Carretero, Boege, DíazCastelazo, Domínguez, \& Rico-Gray, 2016). Consequently, it is intuitive to think that this protection extends to galls that have developed these traits. In addition, the gall's position on the plant and, therefore, in the environment, may determine different survival rates (Leite et al., 2017). Likewise, gall size and parenchyma thickness have already been much tested as traits acting as barriers, mainly against parasitoids (Sopow \& Quiring, 2001; Van Hezewijk \& Roland, 2003; Zargaran, Safaralizadeh, Pourmirza, \& Valizadegan, 2011; Figueiredo, Santos, Fernandes, \& Martins, 2014).

Galling insects sustain a variety of natural enemies that attack them directly as kleptoparasites, parasitoids and predators (Abrahamson, Sattler, McCrea, \& Weis, 1989; Van Hezewijk \& Roland, 2003; Bourg \& Hanson, 2014; Hanson \& Nishida, 2014; Forbes et al., 2015; Luz \& Mendonça Júnior, 2019). Furthermore, some organisms interact with galls consuming the neoformed tissues, such as pathogens, vertebrates (herbivores) or Cecidophages (insect larvae that feed on gall tissues), which can negatively affect the galling insects and even cause their death as a collateral effect (Zamora \& Gómez, 1993; Sugiura \& Yamazaki, 2009; Cooper \& Rieske, 2011; Katilmis \& Azmaz, 2015; Luz, Gonçalves, Moreira, \& Becker 2015; Mete \& Mergen, 2017). Such enemies can include guilds (i.e., functional groups) which pose variable direct or indirect risks to the galling insect. Despite this variety, the parasitoids are the group predominantly studied when considering the relevance of gall traits (Weis \& Abrahamson, 1985; Waring \& Price, 1989; Bailey et al., 2009; Zargaran et al., 2011) and the impact of indirect enemies can be underestimated. This scenario raises questions that need to be adapted to galling interactions in the field, and which aim to understand if a variety of gall traits do in fact function as defenses against enemies. Understanding the importance of aposematism or defense positions, and barrier traits (parenchyma thickness, trichomes and projections) is especially important when considering enemy guilds that may harm galling insects though different mechanisms.

Galls induced by Palaeomystella oligophaga (Lepidoptera) on Macairea radula (Melastomataceae) are conspicuous structures varying in color, size, length of parenchyma projections and the height at which they occur on the plant (Fig. 1). Regardless of these multiple traits, several types of insects attack the galling insect, thus representing an excellent model system. Herein, we characterize this 


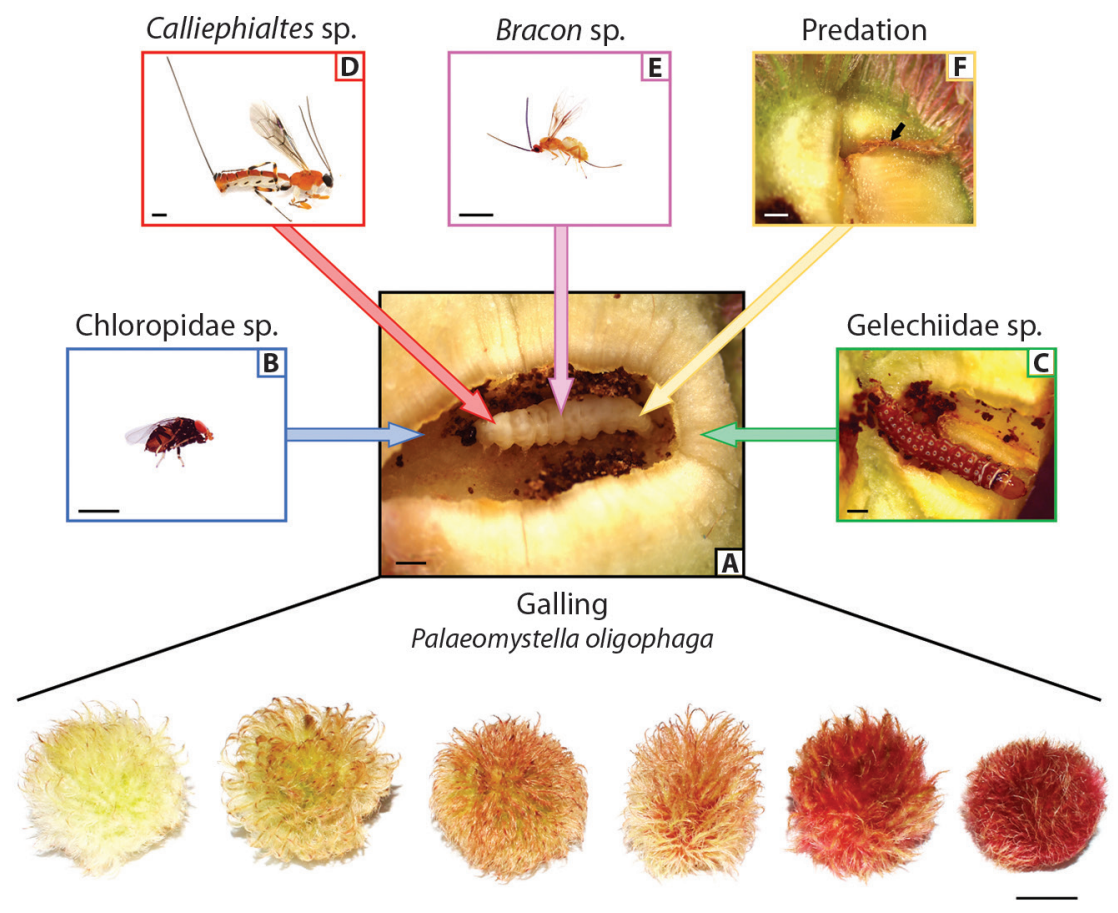

Fig. 1. Trait variation of Macairea radula galls (bottom; scale bar: $1 \mathrm{~cm}$ ) induced by A. Palaeomystella oligophaga and associated enemies. The galling insects are indirectly affected by B. a cecidophagous Chloropidae and $\mathbf{C}$. a cecidophagous Gelechiidae that feed on gall tissues, causing P. oligophaga death. The galling insects are also directly attacked by D. Calliephialtes sp. parasitoids, E. Bracon sp. parasitoids and an F. unidentified predator, which was recognized by the scar left on gall parenchyma (arrow) and the dried galling larva inside the larval chamber. Scale bar: $1 \mathrm{~mm}$.

multitrophic system through categorization of the different enemy guilds present. We identified them to the lowest taxonomic level possible and determined the kind of interaction responsible for galling insects' deaths. Considering the enemy hypothesis and the selection of secondary characteristics, we also aimed to determine which of the multiple gall traits influence the survival success of galling insects in a multi-enemy context.

\section{MATERIALS AND METHODS}

Study site and system: The study was carried out at Panga Ecological Station in Uberlândia municipality, Minas Gerais state, in an ecotone area between a 'wet grassland' and a 'cerrado sensu strictu' (Cardoso, Moreno, Bruna, \& Vasconcelos 2009). Palaeomystella oligophaga Becker and Adamski
2008 (Lepidoptera: Momphidae) (Fig. 1A) is a microlepidoptera that, during the larval and pupal stage, remains inside globoid-shaped galls (sensu Isaias, Carneiro, Santos, \& Oliveira 2014) induced in axillary stem buds of Macairea radula Bonpl. (Melastomataceae) shrubs (Becker \& Adamski 2008).

Procedures: We obtained the samples at the end of the rainy season (April), when all insects (including natural enemies) are found in the pupal stage, permitting us to infer the survival rates of the galling insect at the end of its life cycle. A total of 321 galls were removed from different plants $(\mathrm{N}=321)$. The collection of galls was not replicated in other populations due to the number of samples required for the analysis, restricting the collections to one population where a satisfactory number of galls occurred. We tested the following gall 
characteristics as a potential defensive role: the height of each gall on $M$. radula shrubs, gall volume, thickness of parenchyma around the larval chamber, length of projections, and coloration.

We measured the height of each gall related to the ground on the host plant before removal. In the laboratory we opened each gall for observation and collection of the occupants using a Leica ${ }^{\circledR} 500$ stereomicroscope coupled to the U-photo system ICC50HD. Insects were incubated in plastic microtubules at room temperature until adult emergence and identifications were carried out to the lowest taxonomic level possible. Gall height and width were measured and used to calculate the volume based on an oblate spheroid. Parenchyma thickness was calculated using gall height (from its insertion point on the plant to the opposite surface), discounting the larval chamber height (from the bottom to the top of the wall) and dividing the value by 2 . This calculation provides an average measurement of both the top and bottom of the gall parenchyma. Projections were measured by calculating the average of three projections present on the surface of the gall apex (opposite to insertion point on host plant), since the projections are larger and more homogeneous in size at the apex. We also measured the parasitoids body and ovipositor lengths for a better understanding of the relationships between the occurrence of each species of parasitoids according to the thickness of the parenchyma. All measurements were performed using a digital caliper (Digimess ${ }^{\circledR}$ ZAAS-1.0004, $0.01 \mathrm{~mm}$ readability).

We used the concentration of anthocyanins as a proxy for color pattern, since these are the main pigments responsible for red coloration in plant organs and they provide a conspicuous coloration when accumulated in galls (Connor et al., 2012). For this purpose, we removed the gall projections, set them horizontally in a single layer, exposed them (together) to a handheld USB JAZ spectrophotometer (Ocean Optics $\left.{ }^{\circledR}\right)$ and took the mean of three measurements. We used a standard white (Ocean Optics ${ }^{\circledR}$ ) and the absence of light as black for calibration. We then calculated the Anthocyanin Reflectance Index (ARI) based on the inverse reflectance at $550 \mathrm{~nm}$ (anthocyanin absorption peak) (sensu Gitelson, Merzlyak, \& Chivkunova, 2001). With this procedure, we obtained a scale of anthocyanin concentration. Values close to 0 and 1 refer to greener and redder galls, respectively.

Statistical analysis: The different organisms present in the gall were grouped into three guilds: (1) "galling": galls with the presence of live $P$. oligophaga pupae; (2) "direct enemies": enemies that fed directly on the galling insect; and (3) "indirect enemies": insects that fed on gall tissues, killing the galling insect indirectly. We performed pairwise group comparisons using chi-square goodness of fit tests with equal expected proportions and obtained $P$-values through Monte Carlo simulations (10 000 iterations each). A Bonferroni correction was applied using the p.adjust function of the $\mathrm{R}$ software stats package.

We applied a multinomial logistic model using the mlogit R-package version 0.3-0 (Croissant, 2018) to investigate the traits that influence the presence of different natural enemies in $M$. radula galls, and therefore the killing of $P$. oligophaga. Thus, the presence of a live galling insect was taken as a reference level and the occurrence of each enemy was considered as alternative outcomes. We considered the height of the gall on the plant, its color, length of projections and parenchyma thickness as predictor variables. Gall volume was not used because it had a high correlation of 0.89 with parenchyma thickness. We considered multicolinearity to be no problem among the remaining explanatory variables (below 0.44 in all cases). The significance of the model was assessed by the likelihood ratio (LR) test. Analyses were carried out in the $\mathrm{R}$ statistical environment version 3.5.0 (R Core Team, 2018).

\section{RESULTS}

We found different taxa of insects that interact directly or indirectly with $P$. oligophaga 
(Fig. 1A). Most insect enemies used not only the food resource, but also the shelter provided by the gall structure, forming pupae within, and emerging as adults. Although we have not identified them to the species level, we are confident that each group considered here corresponds to just a single morphospecies. Thus, we found two species of parasitoids, Caliephialtes sp. (Hymenoptera: Ichneumonidae: Pimplinae) and Bracon sp. (Hymenoptera: Braconidae: Braconinae). There were also two morphospecies of cecidophages, which cause the death of the galling insect, despite they do not feed directly on these larvae (Sanver \& Hawkins, 2000). One of them, the Chloropidae (Diptera) (Fig. 1B) occurs only in the larval chamber, where it feeds on the inner cells until pupation. The other one is a species of Gelechiidae (Lepidoptera) (Fig. 1C) which can forms tunnels in the galls. The gallings were found dead while the Gelechiidae larvae were still feeding on the external gall reached the larval chamber, therefore were classified here as cecidophages instead of kleptoparasites, considered as indirect interactors (sensu Luz \& Mendonça Júnior, 2019). One of the parasitoids, Calliephialtes sp. (Fig. 1D), had a larger body size (Mean \pm SD: $9.4 \pm 2.5 \mathrm{~mm}, \mathrm{~N}=10$ ) and ovipositor $(7.9 \pm 2 \mathrm{~mm}, \mathrm{~N}=10)$ than the other species, Bracon sp. (body size: $1.7 \pm 0.9 \mathrm{~mm}$, $\mathrm{n}=10$; ovipositor: $2.3 \pm 1.3 \mathrm{~mm}, \mathrm{~N}=10$ ) (Fig. 1E). Inside some galls $(\mathrm{N}=17) P$. oligophaga larvae were found dried, together with a single scar traversing the whole parenchyma up to the larval position. These signs were considered as a predatory action (Fig. 1F) probably caused by the piercing stylet of an insect.

The rates of enemy occurrence varied among the groups of organisms. We found that only 68 galls out of 321 contained live galling insects (21.2\%) (Fig. 2). The Chloropidae cecidophages were approximately twice as abundant as galling insects ( $\mathrm{N}=131 ; 40.8 \%)$. Calliephialtes parasitoids occurred in greater numbers $(\mathrm{N}=61 ; 19 \%)$ than Bracon $(\mathrm{N}=$ 23; $7.2 \%)$. The Gelechiidae cecidophages occurred in 21 galls $(6.5 \%)$ and predation signals occurred in 17 (5.3\%). When considering insect guilds, we found that galling insects showed the lowest rates of occurrence compared with the enemies, differing significantly from both "direct enemies" (enemies that interact directly with inducer) $\left(\chi^{2}=6.44 ; \mathrm{P}=\right.$ 0.0127 ) and "indirect enemies" (enemies that interact indirectly with inducer)" $\left(\chi^{2}=32.07 ; \mathrm{P}\right.$ $=0.0003$; Fig. 2). The "indirect enemies" were the most abundant group of organisms found in these galls $\left(\chi^{2}=10.28 ; \mathrm{P}=0.0032\right)$.

We found a significant relationship between the natural enemies of $P$. oligoph$a g a$ and the different predictor variables $\left(\chi^{2}\right.$ $=50.03 ; \mathrm{P}=0.0002)$. The probability of

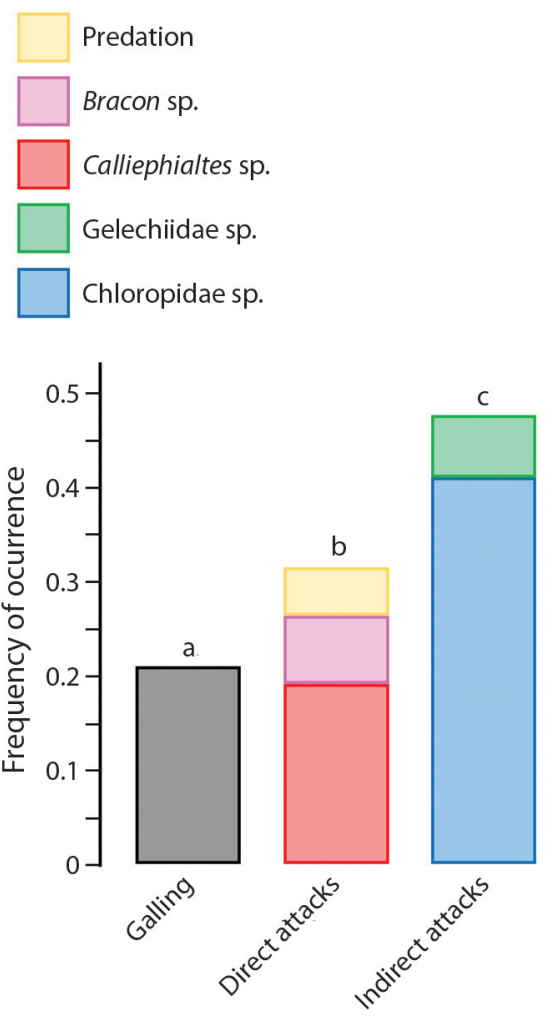

Fig. 2. Occurrence rates of the different organism groups and processes (predation signals) found in galls of Macairea radula induced by Palaeomystella oligophaga moths. Enemies are arranged according to their guilds: "direct attacks" (insects that kill the galling insect by feeding on its body fluids) and "indirect enemies" (insects that feed on gall vegetal tissues, causing galling insect death as a secondary consequence). The letters above the bars refer to the statistical significance. 
incidence of Bracon parasitoids (Odds Ratio $=1.014)$, Gelechiidae cecidophages $(\mathrm{OR}=$ 1.012) and predation signals $(\mathrm{OR}=1.011)$ increased with gall height on the plant (Table 1, Fig. 3A). On average, galls with the presence of galling insects (mean \pm SD height: $86.19 \pm$ $56.26 \mathrm{~mm}$ ) were positioned 42.6, 29.3 and 28.7 $\%$ lower, respectively, then galls with Bracon parasitoids (122.91 $\pm 54.18 \mathrm{~mm})$, Gelechiidae cecidophages $(111.48 \pm 58.59 \mathrm{~mm})$ and predation signals (110.94 \pm 47.59$)$. On the other hand, the probability of occurrence of Calliephialtes parasitoids $(\mathrm{OR}=0.772)$, Gelechiidae cecidophages $(\mathrm{OR}=0.489)$ and predation signals $(\mathrm{OR}=0.654)$ decreased as the average parenchyma thickness was bigger among the sampled galls (Table 1, Fig. 3B). Galls with live galling insects (mean $\pm \mathrm{SD}$ parenchyma thickness: $6.72 \pm 2.07 \mathrm{~mm}$ ) showed 13.8, 29.5 and $22.6 \%$ thicker parenchyma than those with Calliephialtes parasitoids $(5.79 \pm 1.88 \mathrm{~mm})$, Gelechiidae cecidophages $(4.74 \pm 1.52 \mathrm{~mm})$ and predation signals $(5.20 \pm 2.0 \mathrm{~mm})$. There were no effects of color or length of projections (Table 1).

\section{DISCUSSION}

Despite the structural complexity of galls induced on M. radula by P. oligophaga, these insects were attacked by a diversity of organisms. The occurrence rates of the galling moth (taken here as galling insect survival rates) were the lowest, followed by direct enemies and then indirect enemies. Although the protective barrier offered by the gall can work at some level, we suggest that the morphological characteristics analyzed did not constitute an
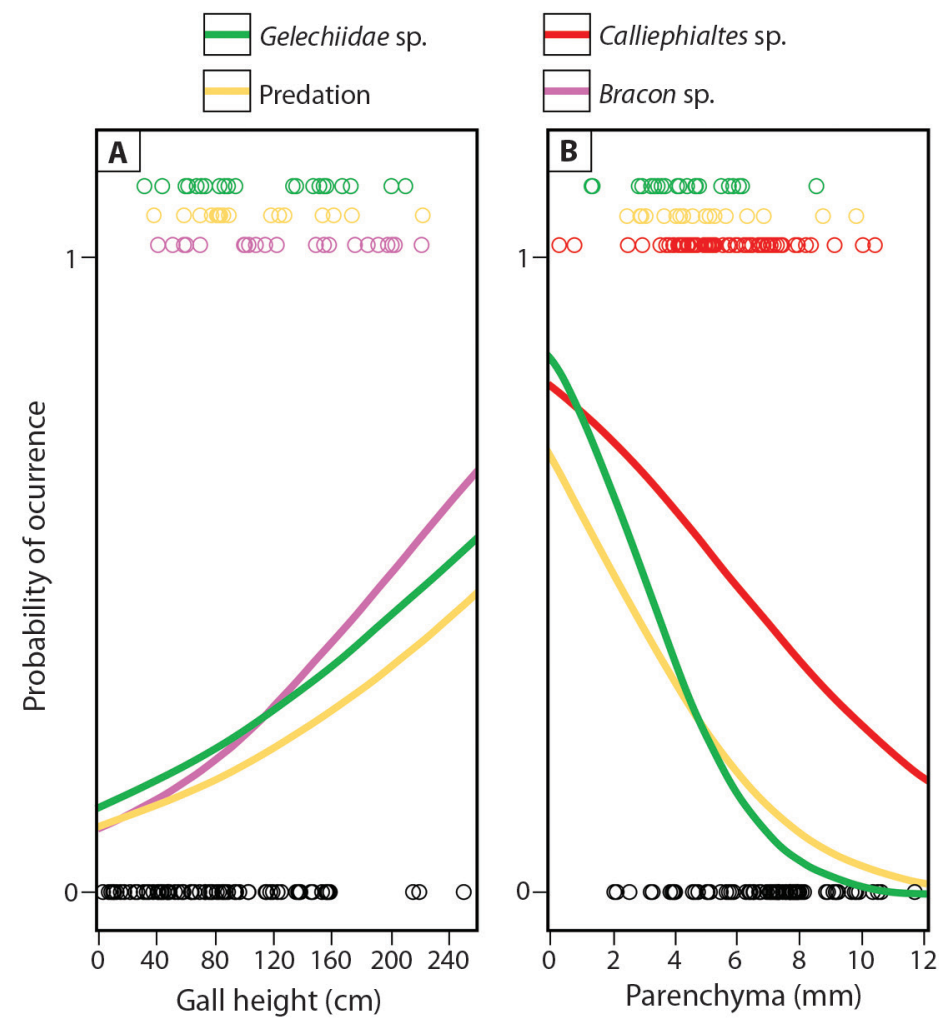

Fig. 3. Frequency of different natural enemies' occurrence according to A. plant height and B. average parenchyma thickness on Macairea radula galls induced by Palaeomystella oligophaga. Circles indicate data distribution; galls with galling insect survival are indicated by 0 (black circles) and those with mortality caused by the different natural enemies are indicated by 1 (color circles). Lines represent predicted probability. 
TABLE 1

Results of multinomial logistic regression demonstrating the relationships between the predictor variables and the occurrence of the different natural enemies, taking the presence of the galling Palaeomystella oligophaga as reference level. Significant results at the 0.5 level are expressed in bold

\begin{tabular}{|c|c|c|c|c|}
\hline Predictor & Natural enemy & Error & $\mathrm{t}$ & $\mathrm{P}$ \\
\hline \multirow{5}{*}{ Color } & Chloropidae & 0.610 & 0.549 & 0.583 \\
\hline & Calliephialtes sp. & 0.719 & -0.249 & 0.803 \\
\hline & Bracon sp. & 0.908 & 0.249 & 0.803 \\
\hline & Gelechiidae & 1.082 & -0.860 & 0.390 \\
\hline & Predation & 1.062 & -0.461 & 0.645 \\
\hline \multirow{5}{*}{ Height } & Chloropidae & 0.003 & 1.439 & 0.150 \\
\hline & Calliephialtes sp. & 0.004 & -0.171 & 0.864 \\
\hline & Bracon sp. & 0.005 & 2.861 & 0.004 \\
\hline & Gelechiidae & 0.005 & 2.438 & 0.015 \\
\hline & Predation & 0.005 & 2.000 & 0.046 \\
\hline \multirow{5}{*}{ Parenchyma } & Chloropidae & 0.090 & -1.455 & 0.146 \\
\hline & Calliephialtes sp. & 0.110 & -2.351 & 0.019 \\
\hline & Bracon sp. & 0.152 & -1.115 & 0.265 \\
\hline & Gelechiidae & 0.172 & -4.146 & $<0.0001$ \\
\hline & Predation & 0.178 & -2.378 & 0.017 \\
\hline \multirow{5}{*}{ Projections } & Chloropidae & 0.065 & -0.445 & 0.657 \\
\hline & Calliephialtes sp. & 0.078 & -0.358 & 0.721 \\
\hline & Bracon sp. & 0.130 & -1.641 & 0.101 \\
\hline & Gelechiidae & 0.111 & 0.594 & 0.553 \\
\hline & Predation & 0.143 & -0.962 & 0.336 \\
\hline
\end{tabular}

effective defense for the galling insect. The threat imposed by Chloropidae cecidophages to $P$. oligophaga supports the importance of considering all kinds of enemy guilds interacting with galling insects when testing hypotheses related to galls. These organisms were not related to any trait studied and posed a greater threat than those insects feeding directly on the galling insect.

The parenchyma thickness was the only negative selective factor in the studied system, against Calliephialtes parasitoids, Gelechiidae cecidophages and predatory attacks. Rossi, Stiling, Strong and Johnson (1992) showed in experiments that the studied parasitoids have no preference for a particular gall size, differing from the data by Weis, Abrahamson and McCrea (1985) where the chances of successful oviposition were lower for those parasitoids, Eurytoma gigantea Walsh (Hymenoptera; Eurytomidae), that attack larger galls due to the time spent on inspection. This pattern also occurred in other systems where galling insects had higher survival rates in larger galls (Sopow \& Quiring, 2001; Cooper \& Rieske, 2010; Zargaran et al., 2011), and thus the parasitoids apparently were more efficient attacking the smallest galls. On the other hand, the parasitoids in some systems showed a preference for the largest galls (Van Hezewijk \& Roland, 2003; Figueiredo et al., 2014). Here, we showed that gall features can work in different ways, against different parasitoid taxa, in the same gall system. Another example are the galls induced by Dryocosmus kuriphilus (Hymenoptera: Cynipidae) in Castanea spp. (Fagales: Fagaceae) which vary in size. The larger galls in this system had a higher presence of Torymus sinensis parasitoids (Hymenoptera: Torymidae), whereas the smaller ones had more Ormyrus labotus parasitoids (Hymenoptera: Ormyridae). This segregation was explained by the differences in ovipositor length between the two parasitoid species (Cooper \& Rieske, 2010).

Our data suggest that galls with parenchyma thickness greater than the average length of Calliephialtes ovipositors (comparing the average size values for both structures) showed the smallest occurrence of these parasitoids. Thus, the negative relation may be a result of a preference for smaller gall sizes or ineffective oviposition in the larger ones, which may lead to selection for increased parenchyma thickness against attack by these parasitoids. On the other hand, the negative relation between Gelechiidae cecidophages and parenchyma thickness seems counterintuitive since it potentially makes available more food and shelter. Predators probably need to have mouthparts capable of reaching the larva in the center of the gall, which may also contribute to selection for greater thickness. 
Gall location influenced the occurrence of Bracon parasitoids, Gelechiidae cecidophages and predators. However, it had no influence on Chloropidae cecidophages probably because these organisms are more adapted to using cues provided by gall metabolism to find their targets (Unsicker, Kunert, \& Gershenzon, 2009; Schaefer \& Ruxton, 2011). Data regarding the number of potential sites per height vs. the number of sites induced may reveal whether galling insects prefer a particular stratum. However, it appears that $P$. oligophaga induces galls on any axillary stem buds available, which can occur at several heights. In this respect, a gall induction made at a random height may determine the probability of exposure to risk of attack by Bracon parasitoids, Gelechiidae cecidophages and predators. Since these enemies taken together occupied $19 \%$ of the opened galls, the choice of induction sites positioned lower on the vegetation may offer an advantage to galling insects. The patterns found here may be related to the natural history traits of the natural enemies, which may fly at greater heights or avoid lower strata in the vegetation.

Finally, despite the wide color variation of $M$. radula galls, we did not find any preferences for green or red ones by enemies. Possibly, the interacting insects do not recognize the conspicuous coloration as aposematic, as the vertebrates' herbivories studied to test the galls aposematic hypothesis suggested by Inbar et al., (2010a). The present data do not support an aposematic function of gall color (at least when considering the studied organisms). The length of projections associated with trichomes also did not relate to the abundance of any of the studied enemies. Still, we cannot rule out the hypothesis that their presence affects attack by generalist herbivores or parasitoids, since they may be so effective against these organisms that we simply did not find them. Galls with a hairy covering may play an important role in galling-insect defense against some parasitoids as occurs in Diplolepsis sp. (Cynipidae) galls on Rosa sp. (Rosaceae) shrubs (Askew, Gómez, Hernández, \& Aldrey, 2006).
However, in these systems parasitism was also sensitive to gall size and thickness (László \& Tothmérész, 2013).

In the $P$. oligophaga - M. radula as system we demonstrated how different gall traits work simultaneously against direct and indirect enemies of galling insects. Although color and trichomes were not effective in reducing attack by the studied organisms, we cannot rule out the possibility that these traits exist as characteristics that have been molded by selective pressure from other natural enemies during evolution. The lack of a relationship between the traits analyzed and Chloropidae cecidophages shows that, despite the apparent defense offered by gall structure, galling insects can support large populations of enemies and suffer high mortality (Waring \& Price, 1989; Hawkins, Askew, \& Shaw, 1990; László \& Tothmérész, 2013).

Ethical statement: authors declare that they all agree with this publication and made significant contributions; that there is no conflict of interest of any kind; and that we followed all pertinent ethical and legal procedures and requirements. All financial sources are fully and clearly stated in the acknowledgements section. A signed document has been filed in the journal archives.

\section{ACKNOWLEDGMENTS}

This study was financed in part by the Coordenação de Aperfeiçoamento de Pessoal de Nível Superior - Brasil (CAPES) - Finance Code 001. The authors are grateful to Fundação de Amparo à Pesquisa de Minas Gerais (FAPEMIG) and Conselho Nacional de Desenvolvimento Científico e Tecnológico (CNPq) for financial support.

\section{RESUMEN}

Características de las agallas, y supervivencia de insectos que producen agallas, en el contexto de enemigos múltiples. Introducción: La hipótesis del enemigo postula que las características de la agalla protegen al 
agallero contra los enemigos naturales. Las agallas muestran una gran variedad de tamaños, colores y adornos, que varían incluso de forma intraespecífica. Sin embargo, los agalleros son objetivos de varios organismos que los atacan directa o indirectamente. En este contexto, considerar solo una característica para investigar la estructura de la agalla actúando contra un solo gremio de enemigos puede ocultar una comprensión de las interacciones a nivel comunitario. Objetivos: Para investigar las ideas presentadas usamos las agallas conspicuas inducidas por Palaeomystella oligophaga Becker y Adamski 2008 (Lepidoptera) en Macairea radula (Bonpl.) (Meslastomataceae) como sistema modelo. Describimos este sistema a través de la categorización de los diferentes gremios enemigos presentes en la comunidad. Los identificamos al nivel taxonómico más bajo posible y determinamos el tipo de interacción responsable de la muerte de los agalleros. Teniendo en cuenta la hipótesis del enemigo y la selección de características secundarias, también buscamos determinar cuáles de las múltiples caracteristicas de la agalla influyen en el éxito de supervivencia de los agalleros en un contexto de enemigos múltiples. Métodos: Inspeccionamos las agallas y caracterizamos los gremios enemigos que afectan al agallero y las tasas de mortalidad producidas por cada uno de ellos. Luego, probamos si las distintas caracteristicas de las agallas medidas (grosor del parénquima, color, proyecciones) promueven la supervivencia de los agalleros con respecto a cada enemigo. Resultados: La mortalidad indirecta inducida por los cecidofagos fue del $47.3 \%$, superior a la causada por los parasitoides y los depredadores (31.5 $\%$ ). Apesar de la complejidad estructural de la agalla, los agalleros vivos mostraron la menor presencia (21.2 \%). El grosor del parénquima se relacionó negativamente con los parasitoides de Calliephialtes, los cecidófagos de Gelechiidae y la depredación. Conclusiones: Demostramos que los ataques a los tejidos biliares por cecidófagos representaron la mayor amenaza para la supervivencia de P. oligophaga. Esto es interesante porque, de acuerdo con la hipótesis del enemigo, la estructura de las agallas debería proporcionar protección para los insectos agalleros en lugar de atraer a los insectos que se alimentan de la agalla misma. Sin embargo, también demostramos que el grosor del parénquima puede estar relacionado negativamente con algunos organismos, especialmente los enemigos directos. Otras caracteristicas hipotéticas como defensivas (por ejemplo, proyecciones, coloración) pueden simplemente no desempeñar ningún papel.

Palabras clave: morfología de agallas; interacciones indirectas; multitróficas; tritróficas; cecidófagos; antocianinas.

\section{REFERENCES}

Abrahamson, W.G., Sattler, J.F., McCrea, K.D., \& Weis, A.E. (1989). Variation in selection pressures on the goldenrod gall fly and the competitive interactions of its natural enemies. Oecologia, 79, 15-22.
Alahakoon, U., Adamson, J., Grenkow, L., Soroka, J., Bonham-Smith, P., \& Gruber, M. (2016). Field growth traits and insect-host plant interactions of two transgenic canola (Brassicaceae) lines with elevated trichome numbers. The Cannadian Entomology, 148, 603-615.

Askew, R.R., Gómez, J.F., Hernández, M.N., \& Aldrey, J.L.N. (2006). Catalogue of parasitoids and inquilines in galls of Aylacini, Diplolepidini and Pediaspidini (Hym., Cynipidae) in the West Palaearctic. Zootaxa, 1301, 1-60.

Bailey, R., Schönrogge, K., Cook, J.M., Melika, G., Csóka, G., Thuróczy, C., \& Stone, G.N. (2009). Host niches and defensive extended phenotypes structure parasitoid wasp communities. PLoS Biology, 7, e1000179.

Becker, V.O., \& Adamski, D. (2008). Three new cecidogenous Palaeomystella Fletcher (Lepidoptera, Coleophoridae, Momphinae) associated with Melastomataceae in Brazil. Revista Brasileira de Entomologia, 52, 647-657.

Bomfim, P.M., Cardoso, J.C.F., Rezende, U.C., Martini, V.C., \& Oliveira, D.C. (2019). Red galls: the different stories of two gall types on the same host. Plant Biology, 21, 284-291.

Bourg, A., \& Hanson, P. (2014). Host specificity of gall midges (Diptera: Cecidomyiidae) on ten species of Inga (Fabaceae). In G.W. Fernandes \& J.C. Santos (Eds.), Neotropical Insect Galls (pp. 151-161). Germany: Springer.

Bronner, R. (1992). The role of nutritive cells in the nutrition of Cynipids and Cecidomyiids. In J.D. Shorthouse \& O. Rohfritsch (Eds.), Biology of arthropods (pp. 118-140). United States of America: Science Publishers Inc.

Cardoso, E., Moreno, M.I.C., Bruna, E.M., \& Vasconcelos, H.L. (2009). Mudanças fitofisionômicas no Cerrado: 18 anos de sucessão ecológica na Estação Ecológica do Panga, Uberlândia-MG. Caminhos de Geografia, 10(32), 254-268.

Connor, E.F., Bartlett, L., O’Toole, S., Byrd, S., Biskar, K., \& Orozco, J. (2012). The mechanism of gall induction makes galls red. Arthropod-Plant Interaction, 6, 489-495.

Cooper, W.R., \& Rieske, L.K. (2010). Gall structure affects ecological associations of Dryocosmus kuriphilus (Hymenoptera: Cynipidae). Environmental Entomo$\log y, 39,787-797$.

Cooper, W.R., \& Rieske, L.K. (2011). A native and an introduced parasitoid utilize an exotic gall-maker host. Biological Control, 56, 725-734.

Croissant, Y. (2018). mlogit: Multinomial Logit Models. R-package version 0.3-0. Retrieved from https:// cran.r-project.org/web/packages/mlogit/index.html 
Danks, H.V. (2002). Modification of adverse conditions by insects. Oikos, 99, 10-24.

Figueiredo, J.M., Santos, J.C., Fernandes, G.W., \& Martins, R.P. (2014). Natural Selection on a Tropical System: Gall-Size Distribution on Waltheria indica (Malvaceae). In G.W. Fernandes \& J.C. Santos (Eds.), Neotropical insect galls (pp. 115-128). Germany: Springer.

Forbes, A.A., Hall, M.C., Lund, J., Hood, G.R., Izen, R., Egan, S.P., \& Ott, J.R. (2015). Parasitoids, hyperparasitoids, and inquilines associated with the sexual and asexual generations of the gall former, Belonocnema treatae (Hymenoptera: Cynipidae). Annals of the Entomological Society of America, 109, 49-63.

Gitelson, A.A., Merzlyak, M.N., \& Chivkunova, O.B. (2001). Optical properties and nondestructive estimation of anthocyanin content in plant leaves. Journal of Photochemistry and Photobiology, 74, 38-45.

Hanson, P., \& Nishida, K. (2014). Insect galls of Costa Rica and their parasitoids. In G.W. Fernandes \& J.C. Santos (Eds.), Neotropical Insect Galls (pp. 497-517). Germany: Springer.

Hawkins, B.A., Askew, R.R., \& Shaw, M.R. (1990). Influences of host feeding niche and foodplant type on generalist and specialist parasitoids. Ecological Entomology, 15, 275-280.

Inbar, M., Izhaki, I., Koplovich, A., Lupo, I., Silanikove, N., Glasser, T., \& Lev-Yadun, S. (2010a). Why do many galls have conspicuous colors? A new hypothesis. Arthropod-Plant Interaction, 4, 1-6.

Inbar, M., Izhaki, I., Koplovich, A., Lupo, I., Silanikove, N., Glasser, T., \& Lev-Yadun, S. (2010b). Conspicuous gall colors: a response to TCR White. Arthropod-Plant Interaction, 4, 151-152.

Isaias, R.M.S., Carneiro, R.G.S., Santos, J.C., \& Oliveira, D.C. (2014). Gall morphotypes in the Neotropics and the need to standardize them. In G.W. Fernandes \& J.C. Santos (Eds.), Neotropical insect galls (pp. 51-67). Germany: Springer.

Katilmis, Y., \& Azmaz, M. (2015). Investigation on the inquilines (Hymenoptera: Cnipidae, Synergini) of oak galls from inner western Anatolia, Turkey. Turkish Journal of Zoology, 39(1), 168-173.

László, Z., \& Tóthmérész, B. (2013). The enemy hypothesis: correlates of gall morphology with parasitoid attack rates in two closely related rose cynipid galls. Entomological Society, 103, 326-335.

Leite, G.L.D., Veloso, R.V.Z., Zanuncio, J.C., Azevedo, A.M., Silva, J.L.C., Wilcken, F., \& Soares, M.A. (2017). Architectural diversity and galling insects on Caryocar brasiliense trees. Scientific Reports, 7(1), 1-7.
Lev-Yadun, S. (2016). Defensive (anti-herbivory) coloration in land plants. New York, United States of America: Springer International Publishing.

Lill, J.T., Marquis, R.J., Cuddington, K., Byers, J.E., \& Wilson, W.G. (2007). Microhabitat manipulation: ecosystem engineering by shelter-building insects. New York, United States of America: Academic Press.

López-Carretero, A., Boege, K., Díaz-Castelazo, C., Domínguez, Z., \& Rico-Gray, V. (2016). Influence of plant resistance traits in selectiveness and species strength in a tropical plantherbivore network. American Journal of Botany, 103, 1436-1448.

Luz, F.A., Gonçalves, G.L., Moreira, G.R., \& Becker, V.O. (2015). Description, molecular phylogeny, and natural history of a new kleptoparasitic species of gelechiid moth (Lepidoptera) associated with Melastomataceae galls in Brazil. Journal of Natural History, 49, 1849-1875.

Luz, F.A., \& Mendonça Júnior, M.D.S. (2019). Guilds in insect galls: who is who. Florida Entomologist, 102(1), 207-210.

Mani, M.S. (1964). Ecology of plant galls (1 ${ }^{\text {st }}$ Ed.). The Hague, Netherlands: Junk Publishers.

Mete, Ö., \& Mergen, Y.O. (2017). The community components associated with two common rose gall wasps (Hymenoptera: Cynipidae: Diplolepidini) in Turkey. Turkish Journal of Zoology, 41, 696-701.

Oliveira, D.C., Isaias, R.M.S., Fernandes, G.W., Ferreira, B.G., Carneiro, R.G.S., \& Fuzaro, L. (2016). Manipulation of host plant cells and tissues by gall-inducing insects and adaptive strategies used by different feeding guilds. Journal of Insect Physiology, 84, 103-113.

Price, P.W., \& Pschorn-Walcher, H. (1988). Are galling insects better protected against parasitoids than exposed feeders? A test using tenthredinid sawflies. Ecological Entomology, 13, 195-205.

Price, P.W., Fernandes, G.W., \& Waring, G.L. (1987). Adaptive nature of insect galls. Environmental Entomology, 16, 15-24.

R Core Team. (2018). R: A language and environment for statistical computing. R Foundation for Statistical Computing, Vienna, Austria. Retrieved from: http:// www.Rproject.org

Rezende, U.C., Cardoso, J.C.F., Kuster, V.C., Gonçalves, L.A., \& Oliveira, D.C. (2019). How the activity of natural enemies changes the structure and metabolism of the nutritive tissue in galls? Evidence from the Palaeomystella oligophaga (Lepidoptera)-Macairea radula (Metastomataceae) system. Protoplasma, 256(3), 669-677. 
Rossi, A.M., Stiling, P.D., Strong, D.R., \& Johnson, D.M (1992). Does gall diameter affect the parasitism rate of Asphondylia borrichiae (Diptera: Cecidomyiidae)? Ecological Entomology, 17, 149-154.

Sanver, D., \& Hawkins, B.A. (2000). Galls as habitats: the inquiline communities of insect galls. Basic and Applied Ecology, 1, 3-11.

Schaefer, H.M., \& Ruxton, G.D. (2011). Plant-animal communication $\left(1^{\text {st }}\right.$ Ed.). Oxford, England: Oxford OUP.

Shorthouse, J.D. (1986). Significance of nutritive cell in insect galls. Proceedings of the Entomological Society of Washington, 22, 368-375.

Shorthouse, J.D., Wool, D., \& Raman, A. (2005). Gallinducing insects-Nature's most sophisticated herbivores. Journal of Applied Entomology, 6, 407-441.

Sopow, S.L., \& Quiring, D.T. (2001). Is gall size a good indicator of adelgid fitness? Entomologia Experimentalis et Applicata, 99, 267-271.

Stone, G.N., \& Schönrogge, K. (2003). The adaptive significance of insect gall morphology. Trends Ecology and Evolution, 18, 512-522.

Sugiura, S., \& Yamazaki, K. (2009). Gall-attacking behavior in phytophagous insects, with emphasis on Coleoptera and Lepidoptera. Terrestrial Arthropod Review, 2, 41-61.

Unsicker, S.B., Kunert, G., \& Gershenzon, J. (2009). Protective perfumes: the role of vegetative volatiles in plant defense against herbivores. Current Opinion in Plant Biology, 12, 479-485.
Van Hezewijk, B.H., \& Roland, J. (2003). Gall size determines the structure of the Rabdophaga strobiloides host-parasitoid community. Ecological Entomology, 28, 593-603.

Waring, G.L., \& Price, P.W. (1989). Parasitoid pressure and the radiation of a gallforming group (Cecidomyiidae: Asphondylia spp.) on creosote bush (Larrea tridentata). Oecologia, 79, 293-299.

Weis, A.E., \& Abrahamson, W.G. (1985). Potential Selective Pressures by Parasitoids on a Plant-Herbivore Interaction. Ecology, 66, 1261-1269.

Weis, A.E., Abrahamson, W.G., \& McCrea, K.D. (1985). Host gall size and oviposition success by the parasitoid Eurytoma gigantea. Ecological Entomology, 10, 341-348.

White, T.C.R. (2010). Why do many galls have conspicuous colours? An alternative $\mathrm{h}$ ypothesis revisited. Arthropod-Plant Interaction, 4, 149-150.

Yamazaki, K., \& Lev-Yadun, S. (2015). Dense white trichome production by plants as possible mimicry of arthropod silk or fungal hyphae that deter herbivory. Journal of Theoretical Biology, 364, 1-6.

Zamora, R., \& Gómez, J.M. (1993). Vertebrate herbivores as predators of insect herbivores: an asymmetrical interaction mediated by size differences. Oikos, 66, 223-228.

Zargaran, M.R., Safaralizadeh, M.H., Pourmirza, A.A., \& Valizadegan, O. (2011). Effect of cardinal directions on gall morphology and parasitization of the gall wasp, Cynips quercusfolii. International Journal of Insect Science, 11, 1-10. 